\title{
Civilisations
}

Revue internationale d'anthropologie et de sciences

humaines

$52-2 \mid 2005$

Museums, collections, interpretations

\section{Portrait of a young Indian Gentleman : Recontextualizing ethnic objects and images of the colonized}

João Pacheco de Oliveira

\section{OpenEdition}

\section{Journals}

\section{Electronic version}

URL: http://journals.openedition.org/civilisations/761

DOI: 10.4000/civilisations.761

ISSN: 2032-0442

\section{Publisher}

Institut de sociologie de l'Université Libre de Bruxelles

\section{Printed version}

Date of publication: 1 June 2005

Number of pages: $105-125$

ISSN: 0009-8140

\section{Electronic reference}

João Pacheco de Oliveira, «Portrait of a young Indian Gentleman : Recontextualizing ethnic objects and images of the colonized », Civilisations [Online], 52-2 | 2005, Online since 02 February 2009, connection on 20 April 2019. URL : http://journals.openedition.org/civilisations/761 ; DOI : 10.4000/ civilisations.761 


\title{
Portrait of a young Indian Gentleman : Recontextualizing ethnic objects and images of the colonized
}

\author{
João PACHECO de OLIVEIRA
}

An ethnographic museum and the objects it contains oscillates between two orders of existence. On the day-to-day level, it engages in an unending struggle against the localized chaos housed within its entrails; working to maintain and improve its contents, which are composed of extremely heterogeneous collections, pragmatically organized displays and disparate classifications. Heirs of the «curiosity cabinets » («cabinets de curiosité »), the collections of kings, princes and distinguished families, these museums operate as an immense reservoir of symbols and messages, a treasury of images no one completely understands, which overflows the uses to which it is put in restricted political and intellectual contexts. The gigantic and fragmentary archives and collections of museums - the result of an apparently disordered process of collective construction seem to belong to the realm of dreams and the unconscious.

A museum is always an orderly place in its formal and public areas, presenting an immaculate view of the universe through its displays and galleries laid out along suggested visitation routes. In the exhibit areas, every piece has a name, a title and a clearly explained functional purpose jotted down on neat note cards. Objects, images, diffuse or convergent lighting, interactivity or contemplation at a distance, sounds, smells - all are just some of the resources utilized by museums to produce meaning in the elaboration of a narrative that implicitly contains an explanatory or classificatory key.

This analytic, conquering and triumphant reason tends to assume two distinct aspects which express different paradigms in the discourse of the human sciences. The first of these, and the oldest, operates through inter- and trans-cultural comparisons producing technological taxonomies and series. This paradigm reaches its intellectual apogee under evolutionism, an intellectual tradition with which it maintains an intimate solidarity. Though it can occasionally present small surprises (when it speaks of different evolutionary lineages, for example, or when it emphasizes the discontinuities and particularities of a given series), the comparative viewpoint seems to co-exist quite comfortably with the colonial discourse; the idea of Western supremacy and the notion of a civilizing mission. 
The second intellectual tradition emphasizes a mono-cultural viewpoint, inserting each object, image, or sensation into a given slot within a discreet socio-cultural totality, seeking to recover original meaning. Sweeping comparisons are substituted by a contextualized and relativistic perspective wherein each piece refers to a closed, unified and singular cultural universe which provides semantics and syntax for understanding.

Both frameworks interact with museum collections in a largely uncritical and nonreflexive manner, understanding as «true » only the most immediate and obvious images and operating within the presupposition that the objects within collections are generally unrelated to one another, their presence within the museum's walls the result of insignificant or anecdotal histories. In other words, both paradigms see items in a collection as a series of unproductive fragments gathered together as if by chance and which - if they are to generate any import at all - must be reordered in different ways, whether following evolutionary taxonomic schemes or a culturally relativist approach.

These paradigms create an imposed and self-centered narrative which, with the blessing of science, produces apparently new data, never questioned, whose meaning has supposedly been completely extracted from their previous form of existence. Within this framework, a markedly realistic and analytical style paradoxically coexists with a certain essentialism - deep dimensions of meaning being supposedly revealed to museum-goers, wrapping spectators in the simultaneous and multi-valenced play of representivity (typical forms), authenticity (original meaning) and enchantment.

An alternative approach to museums and meaning which we attempt to present here is simultaneously more comprehensive and hermeneutic. It does not privilege museums as spaces which formulate messages (exposed in explicit narratives), but as loci for the accumulation of symbols, meanings and emotions referring to a variety of social actors. To do this, it is necessary to begin with the stories deposited in museums' collections and the significance that different social actors attribute to or impose upon the displayed ethnic objects and images of colonized peoples, generating meanings that become incorporated into the very physical being of these objects as they are reinterpreted and re-semanticized in each new context.

This approach seeks to create a radical and profound historicization that reconstructs the play of forces surrounding the business of classification and presentation. It seeks to uncover forgotten and silenced stories, emphasizing the uniqueness of the characters in these narratives and their multiple orientations. It also attempts to recover emotions and feelings that extend beyond arguments, strategies and ideologies. In this way, we seek to blaze a trail for an analitic approach, emphasizing the heuristic function that reflexivity should assume in studies of museums' collections. It must be noted that this is a prerequisite for the emergence of new uses and political performances which harness more democratically and polyphonically the enormous power which museums have in the construction of representations.

This approach seeks to create a radical and profound historicization that reconstructs the play of forces surrounding the business of classification and presentation. It seeks to uncover forgotten and silenced stories, emphasizing the uniqueness of the characters in these narratives and their multiple orientations. It also attempts to recover emotions and feelings that extend beyond arguments, strategies and ideologies. It must be noted that this is a prerequisite for the emergence of new uses and political performances which harness more democratically and polyphonically the enormous power which museums have in the construction of representations. 


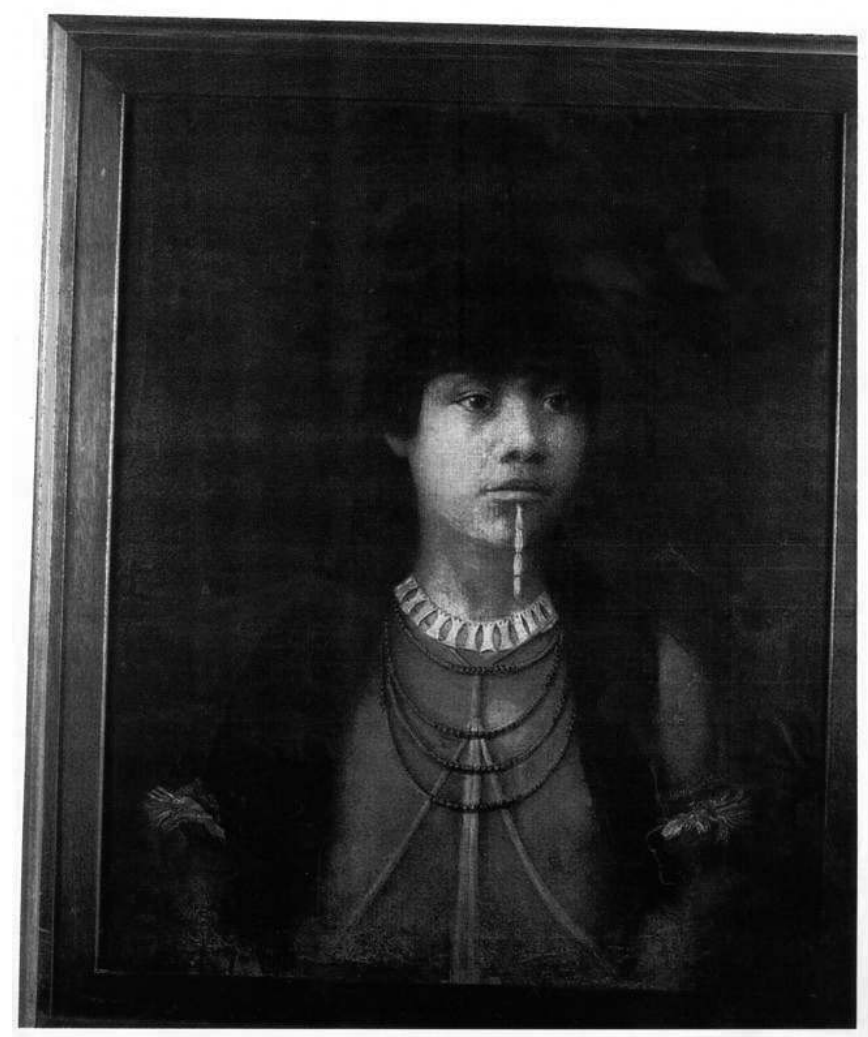

\section{The Adoption of a Little Gentleman (paguemegêra)}

With these considerations in mind, then, let us proceed to the principal topic of this article, an extremely beautiful portrait of a Native American youth, done in oil paints and unsigned, whose name (according to the classification card archived at the Museu Nacional) is Guido. This information is already sufficient for us to begin to classify facts and actors. The painting is of a Bororo boy, adopted when he was approximately seven years old by an upper class Brazilian lady, D. Maria do Carmo de Mello Rego. The boy lived with her and her husband for four years (1888 to 1892), first in the state of Mato Grosso and later on a farm in the interior of Rio de Janeiro, before dying of natural causes, probably pneumonia. The painting is part of one of the Museu Nacional's oldest collections, composed of some 400 indigenous artifacts from Mato Grosso, as well as drawings and paintings, which were donated by the boy's adopted mother ${ }^{1}$.

Adoption is not only a well-known institution in Brazilian society; it is also an important instrument for sociological analysis. Adoption consists of a set of social operations through which one person is incorporated into a social grouping to which he

1. The only study undertaken of this collection to date us that of Vel Zoladz (1990), which primarily focuses upon the esthetic dimensions of the material under consideration. 
did not belong at birth (Weinstein, 1972). It refers to the procedures by which a person is re-allocated from one quasi-natural position to another, " natural » being understood here within the context of the hegemonic rules of descent of the society under consideration.

It is important that the particular character of this adoption be understood before we proceed any further, however, and the two most salient things to be noted here are D. Maria do Carmo's high social position within the Brazilian Empire and the fact that she and her husband treated the Bororo boy as if he were their real child ${ }^{2}$. The quality of this relationship is extensively described in sort of diary, written a few months after Guido's death by his adoptive mother. « I and my husband are old now, childless, without any ties to this life. We concentrated upon him (Guido) all of our affection; all of our care !» (Mello Rego, $1895: 41$ ). « Every day he brought me a beautiful or pleasing leaf, or a flower, which he himself would lay upon my breast - 'I want to dress up my mother', he'd say » (1895 : 37). Without mincing words, D. Maria do Carmo repeated her devoted feelings for Guido : « I loved you, I love you, as only one could love one's most beloved son » $(1895: 24)$.

In another text, which I will describe below, D. Maria do Carmo wrote about practices then in vogue in the state of Mato Grosso, where native children were captured and raised by whites in a replication of slavery, becoming a largely passive and dependant workforce. " They say that the Chamacocos sell their children, but I do not believe it. I think that when they are taken prisoner by the Cadiuéos, the poor children of between seven and eight years are sold... (W)hen I arrived in Mato Grosso, those inhuman purchases were still being made, with prices set at fifty mil réis. A traveling companion who had already studied there told me that he was carrying a hundred mil réis with him in order to purchase two Chamacocos » (Mello Rego, 1899: 182) ${ }^{3}$.

In the diary she tells how she came to adopt young Guido.

One day in Matto-Grosso, as my husband was the President of the province, Captain Antônio José Duarte, the man who had pacified the Bororo tribe, brought us a bunch of Indians for baptism and we became their god-parents. There were two chiefs and I gave them my husband's names: Francisco and Raphael. I treated them as well as I could and gave away many presents. They showed themselves to be very well satisfied, saying through the translator that when they went home to their village, they would return to Cuyabá to dine with us whenever they had quiarigôdo for us (or missed us [sentiam saudades]) (...) Through the interpreter and aided by a small

2. According to a study published by the Revista do Centro Mattogrossense de Letras in 1928, entitled « Dados para a bibliografia mattogrossense », D. Maria do Carmo was born in the Cerro-Largo Department in Uruguay, probably in 1840 (Nadaf, 1997 : 101), and was therefore 48 when she adopted the Bororo boy.

3. Following this passage, D. Maria do Carmo remembered that the custom of buying and selling Indians went against the grain of contemporary Brazilian constitutional law, co-existing with the recent laws that abolished slavery throughout the nation. Her final comments are quite critical of the efficacy of these institutional changes, however : « Who knows how many of these poor little creatures are still enslaved today ! » (idem).

4. Translator's note : both concepts are somewhat alien to the average English-speaker, saudades notoriously so. Translating freely, saudades corresponds to a feeling of bitter-sweet yearning for an object of affection that is no longer present. « Missed» is a gloss that fails to capture the depth of contradictory but generally positive feeling evoked by the word. 
vocabulary list which Captain Duarte had given me, I asked one of the chiefs, the one called Boroiga in the native idiom and to whom I had given the Christian name of Raphael, to send me a little Indian orphan with long hair when he returned to the village. I would raise him as my own child. He agreed to this because he knew I was good and a friend of the Bororós. A month later, on the $12^{\text {th }}$ of June 1888, Captain Duarte brought me a little Indian dressed in a broadcloth shirt and little blue pants. (Mello Rego, 1895 : 9).

In this document, D. Maria do Carmo describes the initial care she lavished upon the recently arrived Native boy : « He didn't know a word of Portuguese and apparently was seven years old, as he had just begun to lose his teeth. I took care of him, bathing him and often sitting on the floor and fanning him until he went to sleep, as he felt too hot. » (Mello Rego, 1895 : 11). Little by little, D. Maria do Carmo's care broke down the boy's barrier of fear and more effective communication began to occur. "When he began to speak, I asked him what he wanted to call me : mother or god-mother. He rapidly answered, without hesitating, that he wished to call me 'mommy'» (1895: 11-12). Guido's name came from one of the saints whose holy day was being celebrated on when the boy came to live with the Mello Regos.

D. Maria do Carmo's emphasizes the boy's orphaned condition ${ }^{5}$ as the reason for his adoption in her version of the story, in which a process of transference of affection is also clearly described. « In a few days he began to show himself as more confident in his affection towards me and he soon began to give me signs of this (...) he had a burning desire that I become his mother, seeing as how his other mother had died when he was very small » (Mello Rego, $1895: 11$ ). The new relationship was already consolidated : « That gentle, pure and seductive child was already now my son » (1895: 12).

Another Indian boy, baptized as Salvador, accompanied them in order to take care of his health when the family returned to Rio de Janeiro from Mato Grosso. Guido was very attached to the boy, whom he called tainó (friend). D. Maria do Carmo says that when Salvador had to return to Mato Grosso she feared that Guido would become sad and so asked him « if he, too, wished go. He rapidly responded, eyes wide : 'Me? Only if my mother goes too ! » $(1895: 35)$ Guido did not want to be separated from his adopted mother and frequently threatened that : " If my mother dies, I will kill myself... » (1895: 21).

Regarding his real father, Guido said that he had been very gentle, often carrying the boy on his hip, even when exhausted or sick, to protect him from the thorny plants which covered the ground. " He had seen him die on the trunk of a fallen tree which served as a bridge over a river» $(1895: 35)$. Though she recognized the strength of this prior relationship, D. Maria do Carmo emphasized the greater emotional linkage to herself which the boy himself often alluded to : « He felt great saudades for his father, but loved me even more » $(1895: 35)$.

5. One of the philanthropic excuses by which the imprisonment and enslavement of young Indians was rationalized in colonial Brazil was that these were supposedly orphans and thus gained a family through adoption into what was effectively slavery. After independence in 1822, legal cases involving Native Americans were the responsibility of the Judge of Orphans and tutelage through adoption was one of the juridical basis's for Natives's special status during the Republican period (Carneiro da Cunha, 1992). 
Guido's relationship with his adoptive father was consolidated more slowly and via other means. While in Mato Grosso, General Francisco Raphael de Mello Rego, provincial president, visited the military fortifications along the border ${ }^{6}$. D. Maria do Carmo relates that Guido was very impressed by the respectful treatment offered her husband by Corumbá's military officials. He began to take a liking to the military men and incorporated the patterns of respect that they showed their superiors into his behavior. He showed great respect to the Emperor Pedro II of Brazil, whom he called Paguemegêra (lord) and was very happy to be baptized on Saint Peter's day.

As Guido grew, he began to accompany his adoptive father on horse rides and to the hunt, activities which the boy enjoyed and showed some skill at. D. Maria do Carmo mentions several meetings with Count d'Eu and his wife, Princess Isabel, noting that the skill with bow and arrow that young Guido demonstrated well hunting was much admired by everyone on these occasions. This familiarity with the imperial family and its notions of hierarchy explains the surprise Guido showed during the following political events. When the declaration of the Republic occurred on the $15^{\text {th }}$ of November, 1889 , Guido « was much afflicted and said, 'My mother, if the military men are so good and the Emperor so great, why did they do this to him ?» (Mello Rego, 1895 : 19).

\section{Indian Ethnography in Mato Grosso}

The intercultural encounter described above was not a simple unilateral and pedagogic project, however, where the tutored apprentice is brought to incorporate the habits and dreams of his tutor, approximating to the ideals of his master. The tutor also had to adjust herself to the situation and mode of interaction, developing behaviors and prioritizing values that permited her to get close to the student, increasing the degree of intercommunication and mutual comprehension? ${ }^{7}$.

This is what occurred in the relationship between D. Maria do Carmo and the Bororo boy. The first movement in this direction was the woman's sympathy for the natives, shown in her constant positive remarks regarding their virtues and abilities, not usually recognized by whites. She describes Pareci women - with whom she had contact during a visit by these Indians to the Cuiabá Palace - as « short, but of very gentle and sympathetic physiognomy » (Mello Rego, 1899 : 176), even calling one girl « beautiful » (1899: 175). Remarking upon the Xingu Indians, she talked about the reports of Lt. Perrot, who was quite impressed with them as « hospitable and industrious » $(189: 177)$.

The second affinitive movement can be found in the intellectual interest which D. Maria do Carmo displayed for the material culture and customs of the Mato Grosso Indians. Paralleling the process of adoption of the Bororo boy, she developed a special interest for indigenous culture, receiving presents, buying things she considered to be beautiful and even underwriting expeditions to sites of archeological interest. During her stay in the province, she gathered some 400 ethnographic pieces from the Bororó, Parecis, Cabixis, Auités, Bakhairis, Cajabys, Guatós, Tapanhunas, Barbados, Sanapanãs, Chamacocos,

6. General Francisco Raphael de Mello Rego was president of Matto Grosso province from the 6 of November, 1887 to the $5^{\text {th }}$ of February, 1889.

7. For a contemporary example of this in ethnography, see the report of the interaction between government agent Manuelão and the Ticuna Indians during the creation of the first indigenous reserve along the Upper Solimões (Oliveira, 1988). 
Guaranys, Cadiuéos and Coroados. D. Maria do Carmo donated this collection to the Museu Nacional, accompanying it with a text she had written regarding the material, which was later published in the Museum's magazine, Archivos do Museu Nacional.

As the Governor's wife, D. Maria do Carmo was in contact with the military officials and scientists who were part of the expeditions to the interior of Brazil. She thus received as presents numerous Indian artifacts and also actively participated in the circulation of information, ideas and values regarding Brazil's native inhabitants. She met Dr. Karl von den Steinen, a famous naturalist, and personally debated with him and other members of the so-called «German Commission» expedition, such as Dr. Meyer Lt. Perrot. She utilized criterion common to German naturalists and ethnologists, referred to as a « salvage anthropology », which gave « great scientific value » to the collection of pieces from tribes which supposedly « would tend to disappear». This seemed to be the case with the Guatós, according to D. Maria do Carmo, who observed that « smallpox have so ravaged this tribe that today they are extremely reduced in number » (Mello Rego, 1899 : 180).

D. Maria do Carmo herself conducted an expedition to São Luís de Cáceres, which recovered several small objects (pipes and pots) and a large funerary urn measuring $95 \mathrm{~cm}$ in diameter (Mello Rego, 1899 : 179). She commented that Dr. von den Steinen himself was quite interested in her discoveries and that even though he couldn't return to the site, he recommended it for a visit by Dr. Meyer. This expedition's report was publicized as a small item of scientific news in which D. Maria do Carmo relates that it was she who had obtained all the pieces of indigenous Mato Grossan earthenware which " our Museum » - the Museu Nacional - contains (Mello Rego, 1899 : 178).

D. Maria do Carmo had enormous respect and admiration for the German Commission and the collection it put together. « The shocking variety of beautiful feather decorations, as well as masks and collars, in which amber appears to be the most beautiful of topazes, was gathered together with rich ceramic specimens which the Commission took most especial care of (...) What joy they must have felt, well rewarded for the fatigue from which they suffered, when they presented their precious collection from the backwoods of Matto Grosso to their colleagues in Europe !» Situating herself on the same level as the foreign naturalists, D. Maria do Carmo added a commentary of her own, indicating her worries regarding the preservation of items of national cultural heritage : «I still feel in my Brazilian heart the leaden weight I felt upon examining that splendid collection of artifacts which went to enrich the Berlin Museum... » (Mello Rego, 1899 : 178).

When compared with post-Malinowskian ethnographic works, D. Maria do Carmo's reports certainly lack a certain qualitative dimension. However, this does not make her descriptions qualitatively different from those given by contemporary naturalists and scientists then exploring the Brazilian backlands. Though she lauded «the savage's innate artistic taste », she also mentions that « they are apparently indifferent (...) to the rigors of nature » (Mello Rego, 1899: 175). She mentions the existence of the "fierce Cabixis », characterized as « cruel and indomitable neighbors », who had until recently been a «terror », committing « every sort of barbarity » (1899: 176). In the book cited above, D. Maria do Carmo also offered readers two negative characterizations of Indians, calling them « vengeful» and « indolent» (Mello Rego, $1895: 13,18$ ).

Though contact with the members of the German Commission and the writers and intellectuals of Rio de Janeiro stimulated D. Maria do Carmo's interest in ethnography, leading her to form scientific collections and write short articles, we shouldn't forget that 
this was also a means for her to attempt to comprehend and value the prior existence of her adopted son. She was especially interested in little Guido's people of origin and her Bororo material, consisting of some 240 pieces, is by far the largest and most complete of the collections she donated to the Museu Nacional. She described the ceremony in which Bororo boys had their lower lips perforated with great empathy and respect, comparing it to Christian baptism. That this sympathetic ethnography was not unconnected to her emotional life is a fact expressed at the end of her report, which she closes by saying that in this manner her adopted son was given the Bororo name " Piududo» (« hummingbird $»$ ).

This emotional dimension is also apparent in D. Maria do Carmo's report regarding the Indian's supposedly vengeful character, which is presented by her as another scene of filial love : Guido's fury directed against a maid who dropped a suitcase lid on D. Maria do Carmo's hand ${ }^{8}$. She claimed that every time Guido recalled the incident, thinking that it might not have been accidental, the boy complained that it was a pity he hadn't killed the servant (Mello Rego, 1895 : 13). This also reveals that Guido had some notion of his relative importance within the strongly asymmetric social universe into which he had been installed.

\section{A Developing Artist}

Moving beyond the ream of emotion, we must ask ourselves what was the objective towards which D. Maria do Carmo directed her pedagogical activities in relation to the young Bororo? In the beginning of the relationship, nothing was clear aside from that which she categorically rejected - the incorporation Guido into Brazilian society as a dependent and unpaid worker - and the affirmation that the boy would be raised as a true son. Little by little, however, the child began to show signs of possessing certain abilities which his tutor decided to stimulate.

« The child's activities were such that even when he was abed sick, he was surrounded by pencils, paper and little tools. He made little boats out of wood, including their rigging and etc. He painted boats and spent entire days, sometimes inventing machines, building artillery pieces, pistols and etc. or drawing ships, people and landscapes » (Mello Rego, 1895 : 17). It's as if in constructing objects and images, Guido reestablished his own interior balance, appropriating from different worlds to reunite and conciliate elements of his past and present.

One activity soon passed to the fore, however : drawing and painting. « Accustomed to seeing him scribbling away, I began to pay attention to what he did. He told me not to peek, because he wanted to surprise me and when he was finished he gave me the paper : 'Here is (a picture of) Bororó fishing, which I made for my dear mother' » (Mello Rego, 1895 : 17). D. Maria do Carmo made her premises explicit and extracts a conclusion from the facts as they appeared to her : « He never had a drawing lesson. He was an intuitive artist and must have been a genius. He was singularly alive, observant and had a frightening ability to easily comprehend things. He overcame all difficulties, demonstrating the sharpest intelligence... » $(1895: 18)$.

8. When she described Indians as « indolent », D. Maria do Carmo also took pains to praise the Bororo boy, describing the intensity and obstinacy with which he attended to his duties. 
From small notebooks, Guido graduated to larger pieces of paper, furnished by D. Maria do Carmo. His 329 drawings today take up three portfolios, organized by his adoptive mother, and constitute an extremely rich and varied set of images, expressing the imaginative world of a young Indian boy taken in by a wealthy, educated Brazilian family.

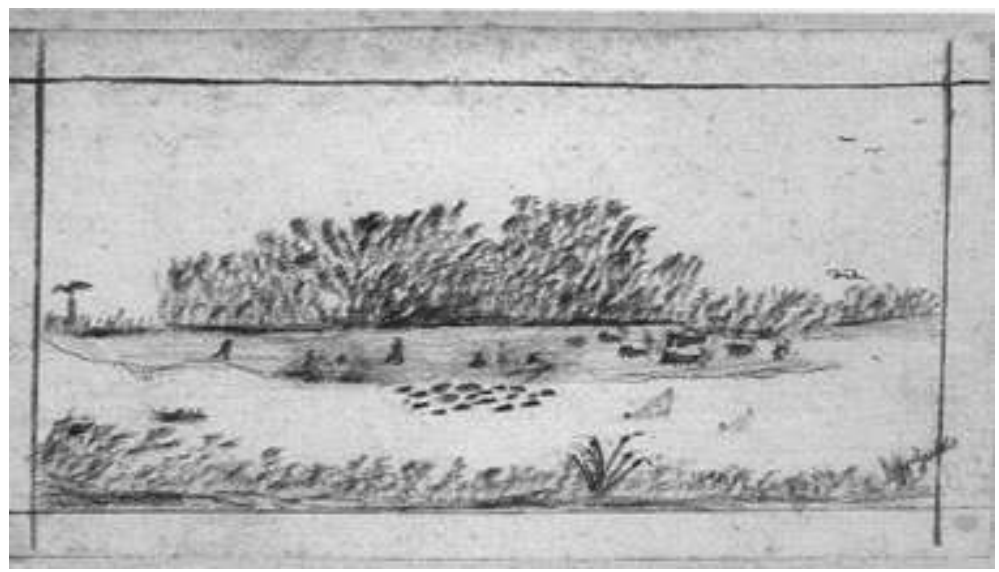

Indians fishing along the river Share

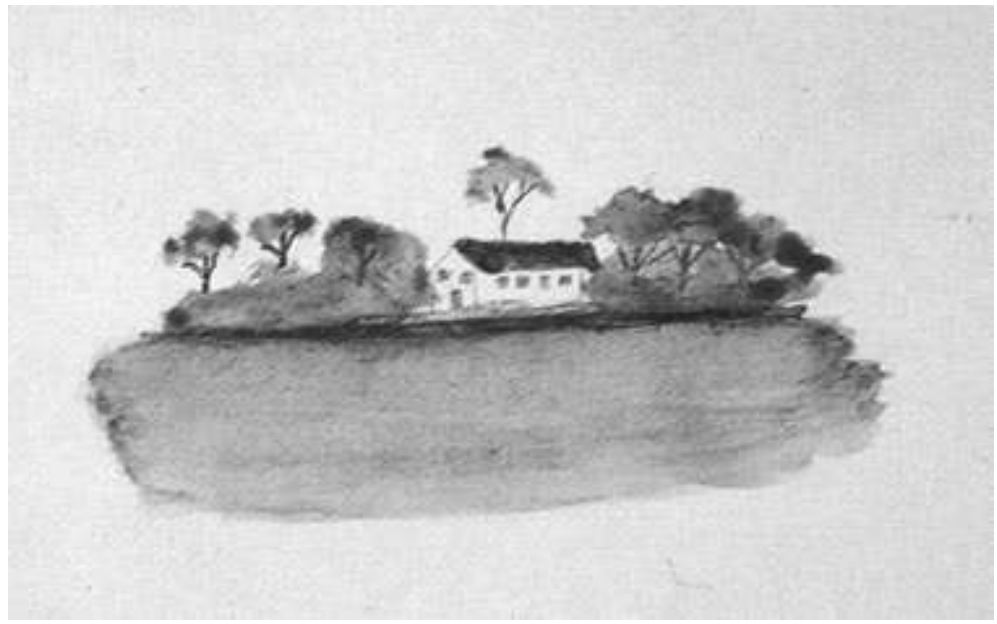

White man house

The drawings are largely reproductions of the landscape of the interior of Mato Grosso; human figures rarely appear in them. Plantations also occasionally appear and these drawings are more elaborate, transmitting the impression that the farms are on an island, surrounded as they are by and emphasized against the forest. This is the civilizatory nucleus which Guido chose to emphasize in his reproductions, strongly distinguishing it 
from the « arranchamentos » (ramshackle dwellings), a word used by his adopted mother to indicate both Indians dwellings and those of backwoodsmen.

\section{The Paradigm of Indian Inferiority}

Adoption can be used as a metaphor with which to think upon the « colonial encounter » (Asad, 1973) in its more quotidian and individualized dimensions. It refers to procedures by which people of one society and culture become routinely sucked and incorporated into the institutions and groups of another society and culture. It is in this sense that we work here with the notion of tutelage as a manner of domination through which indigenous people become described as the natural carriers of a politicized and generic indianness, imposed upon them by colonial situation in which they find themselves (Oliveira, 1988).

The inculcation of habits appropriate to the insertion of natives within a colonial situation is frequently executed through peoples, roles and institutions which remind one of a figure generally found within the familial sphere - the nanny (Payne, 1977). Missionaries often substituted indigenous families with mechanisms such as the native boarding school, a practice which continues today ${ }^{9}$. Many and varied are the manners in which this instrument of sociocultural mediation has made itself felt in the lives of indigenous peoples. Churches, boarding schools, military or civilian administrative units, economic development teams, temporary migrations and etc. - all incorporate disciplinary objectives which are more or less explicit and defined.

The practices of interethnic adoption should also be seen in this light, as a way of undertaking the disciplinary function of cultural intermediation. When the social contact environment is strongly homogenous, this passage can often be realized through a single ritual intervention, without leaving accentuated marks. When the difference between knowledges and powers that are implied in being a member of either group is very great, the instruments of social mediation can no longer be sporadic and/or occasional, but must instead include continuous action, specific roles and a regulatory authority. White adoptive mothers or step-mothers of indigenous children must therefore be considered within a sociological perspective and not simply understood via their individual or conscious motivations.

D. Maria do Carmo's projects with relation to Guido conflicted with then hegemonic concepts circulating among intellectuals and the social networks in which she lived. In this scenario, the theories of Batista de Lacerda - later Director of the Museu Nacionalregarding indigenous racial inferiority occupied a predominant role (Schwarcz, 1993). This inferiority was supposedly publicly and scientifically proven by diverse anthropometric studies and mechanical tests realized during the 1882 Exposição Anthropólogica Brazileira in Rio de Janeiro (Nascimento, 1991 and Morel, 2000).

The concept of race occupied a central place in $19^{\text {th }}$ century thought, with extensive elaboration in France and Germany through physical anthropology and geography, respectively. In Brazil during the second half of the $19^{\text {th }}$ century, romanticism progressively lost ground to an evolutionist science anchored upon the idea of race (Carneiro da Cunha, 1992), which proposed an experimental science of physical types utilizing determinisms based upon biological or climatic factors (Faria, 1993).

9. In certain contexts this was repeated by official indigenist policies. For an analysis of this aspect of things, see Lima (1994) and Machado (1994). 
D. Maria do Carmo's desires and objectives therefore apparently clashed with the scientific facts which supposed the uncivilizability of Indians. The tragic end of her adoption experiment was predictable according to the customs and usages of the society in which she lived (where Indians were incorporated into white families as mere « agregados » (NT : literally « aggregateds »), a disguised form of slavery harshly criticized by D. Maria do Carmo) and also according to the scientific theories of the times. Indian individuals supposedly had lesser chances of adapting themselves to the sophisticated arts of civilization and court life than they did to the brutal routine of manual and unskilled labor on the plantations of Mato Grosso ${ }^{10}$.

Because of her elevated social position, D. Maria do Carmo was not restricted in the kinds of relationships which she could choose to establish with a native child. However, this does not mean that she was free from evaluation and criticism by her contemporaries, who generally believed in biological determinism and implicitly condemned the failure with which her experiment in interethnic living was anticipated.

\section{The Romanticist Discourse}

On the $26^{\text {th }}$ of January 1892, the Bororo passed away on the São Paulo plantation at Mendes in the state of Rio de Janeiro. Inconsolable, his adoptive mother wrote a letter to the Viscount de Taunay, informing him of the news. Two months later, she committed to paper her description of the boy's last months of life. In August of this same year, responding to de Taunay's proposal that she organize a book relating her story, D. Maria do Carmo wrote a third letter. « The pages of this little book would be a loving tribute to the memory of him who so, so loved me and to whom I was so devoted » (Mello Rego, 1895 : 30). These letters would become the three chapters of a small book entitled Guido (Páginas de Dor) (Pages of Pain), published three years later in 1895 in Rio de Janeiro by the well-known printing house Typographia Leuzingerda and containing a preface written by the Viscount de Taunay.

What for scientists would be understood as fate is presented within the pages of this book through the lens of romanticism as a sublime tragedy. This character is underlined by the Viscount's introduction which tells us of a « deep and beautifully, though painfully, expressed occurrence ». " Guido, handsome Guido, enchanting colibri" of the virgin jungles of Mato Grosso, shined for a moment like a brilliant arrow of light penetrating into the breast of the dense forest and suddenly disappeared into the shadows of mysterious and immeasurable darkness $»$ (Mello Rego, $1895: 6$ ).

Guido's death and the failure of the experiment of incorporating an Indian into the most elevated strata of Brazilian society served as a narrative event which exemplified the

10. Even Rondonian indigenism, put into practice in succeeding decades and which incorporated Indians under the tutelage of the Union, transforming them into sedentary residents of reservations or even into telegraph workers along the Mato Grosso lines, interfered less radically in daily routines and environmental connections than the regime under which the Bororo was adopted. At the base of this positivist pedagogy one finds the notion of the avoidance of trauma, " progress » arriving step by step in distinct evolutionary phases.

11. According to the dictionary «colibri» is a word with an indigenous origin (Galibi), incorporated into French; the more usual name for this bird in Brazil would be « beija-flor » (NT : literally « flower-kisser »hummingbird in English) or, among the rural populations of the Southeast « cuitelo » (Buarque de Holanda, 1975 : 346-408). 
period's scientific concepts. On an individual level, it also perfectly expressed a common discursive pattern, wherein the pre-existing conditions of the Indians are compared to a mythical " golden age » and native peoples' historical trajectory is necessarily described only in terms of tragedy and destruction (Bruner, 1986).

On the narrative plane, the racial theories of the $19^{\text {th }}$ century would be later replaced by the discourse of acculturation, dominant within North-American anthropology during a certain period. Likewise, the simple condemnation of the members of a given group in function of their supposed biological destiny has been would eventually be replaced by an interminable sequence of interdisciplinary studies of anomie, marginality and multiple social pathologies (alcoholism, violence, personality disintegration, community linkages, etc.). Almost 100 years later, Indians continue to be interpreted in the light of a paradigm of their inevitable extinction and supposed inadequacy for life in the modern world. This is even true in the case at hand, as the artistic manifestations of the Bororo boy continue to be interpreted through the lens of acculturation and notions of the " marginal man " (Vel Zoladz, 1990).

Guido's elevated social insertion, with a highly educated and sophisticated adoptive mother and an adoptive father who was the President of the Province of Mato Grosso, makes his case absolutely unique. The boy saw himself as a little Paguemegêra, the equal of his father and also somewhat similar to the Emperor of Brazil. This gave young Guido a singular and original alternative in his lived cultural encounter between colonizers and colonized, permitting him to develop aspects of his intellectual and artistic capabilities without needing to completely reject or avoid his indigenous condition.

This is what D. Maria do Carmo informs us of when she relates the boy's singular interpretations of certain episodes in Brazilian history which often stigmatize Indians in the Brazilian school system, leading to their rejection. We're speaking in particular of the episode involving the Bishop of Bahia, D. Pero Fernandes Sardinha, who was devoured by Caeté Indians following a shipwreck. Upon hearing this story, Guido was said to have made the following comment, which clearly reflects the conflicts and persecutions which the Bororo suffered and which the boy had lived to prior to adoption : " The poor Bishop. It happened because the Indians thought he was the one who ordered them killed (Mello Rego, 1895 : 19-20)».

It's worth noting that the boy felt no sense of shame or guilt when faced with this event, things often encountered among Indians (adults and children) when confronted with facts that attempt to personally connect them to institutions which are strongly stigmatized by whites. Guido made a very knowledgeable comment without condemning the executors of the act. He did not associate them with «cruelty » (innate or culturally inculcated), which would have been the most common contemporary reading of the event, but with the violence directed against Indians, advancing an hypothesis that the Bishop's death formed part of a strategy of reprisals.

Another explanation appears following this first one which reflects even more clearly Bororo's singular history of cultural contact. Guido raised the hypothesis that perhaps the Indians in question were allies of the Kayapó, the Bororo's most feared neighbors. In this sense, the boy also put into question a generic and homogenizing discourse regarding Indians. His evaluations are quite different from those of Indians incorporated into the lower strata of white society, who are induced to hide their own traditions and reject their own values. As a « little gentleman », Guido did not need to completely disconnect 
himself from his Bororo past and could incorporate this into the construction of his own individual identity, making use of the freedoms given him by his adoptive family.

\section{The Forged Representation}

Face to face with Guido's portrait, one feels oneself transported to other times and histories, freely navigating through shadows and light, fascination and mystery. We do not perceive that we are caught in a web that was slowly and carefully woven by D. Maria do Carmo. « Someday, a curious person will ask, "Who was this Guido de Mello Rego ? » (Mello Rego, 1895 : 42). This question can also guide us, as we shall see below, to the ethnographic pieces which compose the collection.

Recapitulating, we saw how the boy Piududo, adopted by a wealthy and cultured family, was transformed into young Guido, promising artist (painter). His premature death destroyed his adoptive mother's plans, but also served to ratify - in the eyes of the period's scientists - the thesis of indigenous inferiority, underlining the supposed unsuitability of the Indian to civilized life.

Following upon these facts is a second movement, entirely executed by D. Maria do Carmo, where Guido becomes enshrined as a legacy. «I presented the Museu with the important collection of Indian artifacts that I had gathered and saved for my son, under the condition that they be conserved in his name wherever they are placed (...) Dr. Ladislao Netto, who knows and appreciates their value, happily accepted this condition and put them in a special cabinet. The portrait of him (Guido), which I had had painted, will also belong to the Museu and to this collection after my death » (Mello Rego, 1895 : $41-42)^{12}$.

In the year 1895, in which Guido : Paginas de Dor («Guido: Pages of Pain ») was published, D. Maria do Carmo gave to the Museu Nacional her collection of ethnographic pieces from Mato Grosso, a collection named, at her request, " Guido ». Her final words in the text which accompanied this collection make it clear that one can't consider as separate the two images we have of her, on the one hand a person interested in the ethnography of indigenous Mato Grosso and on the other the adoptive mother of a young Indian lad transformed into a budding artist. « By bringing this short report to an end, I must confess that while writing it, no other sentiment dominated my being or inspired me than my incessant memories of and deep yearning for (saudade) my unforgettable and adored Guido » (Mello Rego, 1899 : 184).

Dead as an individual, Guido now returned as a symbol, completely linked to his adoptive mother through a double reality as a character in a tragic literary narrative and as a name for a scientifically and artistically valuable collection. Romanticism and racial theories, art and science, struggled for the power to interpret and predict the destiny of the young Indian, this being ultimately reflected in the possession of the Bororo boy's portrait which synthesized, harmonized and dissolved these polarities.

The portrait remained with he boy's adoptive mother until she died, then passing into the possession of the Museu Nacional. Respect for the profound anguish of such an eminent personage removed this case from the application of the normal rules ${ }^{13}$.

12. Ladislao Netto was a renowned scientist who was the director of the Museu Nacional from 1874 to 1893 (Schwarcz, $1993:$ 71).

13. During this period Batista de Lacerda was the director of the Museu Nacional (Schwarcz 1993). 
The subject (emphasized by the portrait and subtly condensed in it) shifted over to the field of art, being understood as a human tragedy. Encouraged by the Viscount de Taunay, D. Maria do Carmo would later produce as small book relating her travels, published by Typ. Leuzinger in 1897 and entitled «Lembranças do Matto Grosso (Memories of Mato Grosso) », wherein she recounted some episodes which occurred during her stay in the province. This book was dedicated to Viscount de Taunay « who has shown such sympathy for Matto-Grosso and with elegant pen and enchanting propriety has described many of the most beautiful sites » (Mello Rego, 1897 b).

In her third card to de Taunay, D. Maria do Carmo reveals an interesting clue : « I've had a portrait made in Paris. Would you like To see it when it arrives ? » This was written on the $26^{\text {th }}$ of August, 1892, exactly seven months after Guido's death. Among the last elements of the collection, which arrived as part of D. Maria do Carmo's will, there are two photographs in a table-top picture frame. In one of these photos, Guido is standing alone; in the other, he appears seated on a fake rock with an Indian boy at his feet lying upon a jaguar skin while propped up upon his right elbow. These were the photos, taken years earlier, which went to Paris and which were used as the basis for the portrait commissioned by D. Maria do Carmo.

If, instead of falling into pure enchantment, we try to understand the complex set of refractions which unites the material and/or imagined dimensions involved in the making of museum collections, we will discover a surprising fact: the standard of this set of refractions, the key which is used to access this tragic and human experience, Guido's portrait, is based upon a scene which never existed. The painter and the Bororo boy never met each other!

In both photos, Guido appears with a beautiful lip ornament, similar to that in the portrait; all other parameters were modified, such as the Bororo armbands and necklaces (which were reduced in size and complexity), the mother of pearl necklace, which had been given to him by his adoptive mother (which was increased in size) and the feather headdress (entirely eliminated from the portrait). In the photos, Guido is positioned fully in front of the photographer and looks at the camera with an inquisitive eye; in the portrait, he appears at an oblique angle, looking off towards the horizon with distant and reflective expression on his face. The portrait, painted in Paris by an anonymous artist, and which, among other cultural refractions, plays down possible racial markers juxtaposes the estheticized figure of young Guido against the eyes of the boy he called « Tainó ». The Guido which we observe in the portrait and which gives name to the oldest extant ethnographic collection from Mato Grosso isn't exactly Guido de Mello Rego, adoptive son of D. Maria do Carmo, nor the Bororo boy (« Piududo ») : he is a fusion of the images of two Bororo boys realized by a distant painter who never saw either in the flesh.

\section{Ethnographic Collections as Historical and Cultural Sources}

If we must be cautious when faced with the portrait's illusion of authenticity when representing either a Bororo boy or D. Maria do Carmo's adopted son, we must also rethink the often estheticized uses of ethnographic collections which end up merely accessing and reinforcing stereotypes. When used simply as examples of «Bororo culture », these pieces only help to crystallize prejudice, political exclusion and erroneous analytic constructions. 
The entirety of this ethnographic collection was gathered during the years of the socalled «Bororo pacification $\rangle^{14}$. Karl von den Steinen briefly described this scenario, estimating that the Bororo population was once around 10000 . He also relates that during his scientific expedition to Mato Grosso, he met a planter who claimed to have killed over 450 Indians and imprisoned more than 50 during six years of life in the country ! (Steinen, $1940: 572$ ). These facts are profoundly shocking to today's reader, and even after the strong demographic recovery of the last few decades, today's Bororo number 914 (according to estimates given in Ricardo, 1995).

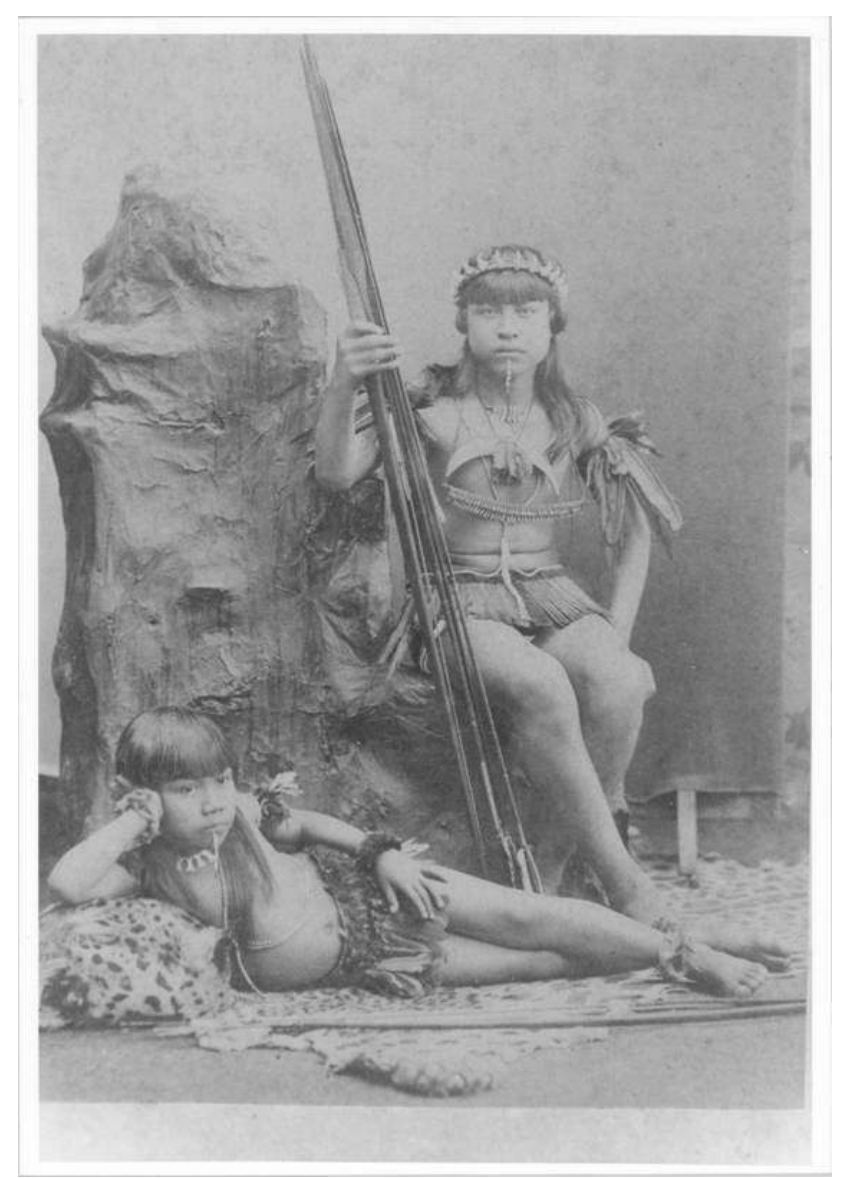

The objects in the collection - arrows, bows, necklaces, clubs and head-dresses used by indigenous leaders - were once presents offered by chiefs upon their baptism as Christians, proof of their friendship and celebration of peace with the whites. They are, generally speaking, extremely valuable and unique objects, coming as they do from historically defined people and collectivities who gave up rare cultural objects in order to establish and alliance with and submission to the Emperor and his representatives.

14. A recent study of the " pacification " process based upon the life of a remarkable woman, Rosa Bororo, was written by Almeida in 2002. 
These pieces were given to D. Maria do Carmo's husband by the military officers directly responsible for the " pacifications ». This is obviously the case of the curuguga, a type of necklace made of hawk's feathers which only the principal chiefs could wear, and which entered into the collection as a gift given by its owner, " great chief Moguiocuri » (Mello Rego, 1899 : 183).

The uniqueness and meaning of this collection is constructed against a historical backdrop of warfare, expeditions and treaties which compose the conquest of Mato Grosso and its natives. The objects of the collection, when juxtaposed against the historical processes whose main actors appear in D. Maria do Carmo's testimony, are revealed as objects of enormous significance for the history of the Bororo and of the colonization of Mato Grosso.

The collection of indigenous artifacts from Mato Grosso, like other old collections of the Museu Nacional, has a unique, known historical background, part of which has been the long voyage they have taken from existence in social life to museum artefacts. In order to have a notion of the tragic and violent historical trauma that was the scenario for this endeavor, it is enough to cite D. Maria do Carmo's own explanation of why the points of some of the collection's arrows were ruined : they were « ripped out of the body of an unlucky fellow found dead on the Vila Bela highway » (Mello Rego, 1899 : 176).

A properly trained ethnographer today would write up an individual card for every piece brought in from the field, indicating its owner or fabricator, family, ethnic group, the local where it was produced and/or obtained and what it was produced and obtained for. D. Maria do Carmo did not leave us with such a minutely detailed record, but in her report she mentions the origins of several of the pieces. These are very important descriptions, not only from the historical point of view, but also in terms of any interpretation of their meaning.

A quick recourse to fiction might help illustrate this new agenda of activities. A novel written by Agualusa (2000:31) contains a curious character, the Portuguese restorer Lili who, in her master's thesis, sustained that the use marks she left upon a book were part of her history and thus shouldn't be eliminated. If we leap from the libraries and archives to the domain of ethnographic collections, we can observe - following Lili's precept - that the dramas, dreams and arguments which motivated their incorporation into a Museum's archives are themselves part of the many levels of meaning with which these objects are invested. These meanings are thus themselves worthy of scholars' attention.

For the descendents of the indigenous peoples who were the objects of these policies of contention and subordination, such meanings offer a rare opportunity to recover knowledge, signs and events that have been rubbed out by official historiography. The holdings of public institutions such as museums and historical archives can - and should - be used to celebrate and increase the legitimacy of subaltern histories and oral traditions.

In order to collaborate with these initiatives, museums must modify their work postures regarding collections of ethnic objects. They must quit focusing on these objects as naturalized expressions of social entities, evaluated by their supposed authenticity and exemplar function. These outdated postures had a paralyzing political function, however unconscious, which established control over the signs that permit elaboration of narratives regarding historical facts, making impossible the construction of counter-discourses that are more faithful to indigenous experiences. 


\section{Towards a Recontextualization of ethnographic Collections and Museums}

In 1999 and again in 2002, we received a visit from the leaders of nearly 40 indigenous peoples from different regions throughout Brazil at the Museu Nacional ${ }^{15}$. We took them to visit our collections and to converse with the restorers, curators and directors of the institution. Through this process, we were able to better identify the components of the duplicity discussed above. Museums can be quite useful to indigenous peoples suffering from violent processes of deculturation and attacks against native values, technologies and know-how. The museum is a powerful instrument which can inculcate and reinforce identitary demarcations, rejecting the prejudice and invisibility which such collectivities are subject to in other contexts. In this sense, museums can be a fundamental ally in the struggle for special rights and modes of life which are more adequate for native peoples.

On the other hand, there is always a level of suspicion involved in this relationship because museums possess a terrible power: that of being able to classify living collectivities, inaugurating processes of definition which are exterior to these collectivities and which escape their control, but which are given a high degree of visibility and social legitimacy. This is a question of the greatest importance on the political agenda of Brazil's native peoples, because when it is linked to the theme of land, legal and administrative questions concerning the recognition of people and collectivities as indigenous inevitably arise.

In other words, when we give value to certain indigenous productions, transforming these in "typical objects » or items worthy of esthetic appreciation, we enter upon a perilous path, running a grave risk of forgetting, minimizing or refusing to look at other productions which are then condemned to be cast aside and forgotten. There is a very great fear that museums' authority in speaking about these peoples and cultures might at some point be used to justify the refusal of recognition as « legitimate » collectivities, families, or leaders who identify themselves as indigenous but are not seen as such by large sections of the public.

A museum is a city of objects, images and messages in which people and collectivities are represented. After all, one of the museum's principal jobs is to personify those whom are absent. A museum always creates a basic division among peoples, separating these into those who come to look into the display cases and wander the rooms, for whom presentations are prepared, and those who are supposedly represented by the items on display and which are themselves the object of scrutiny. This second group of peoples is never totally contained by the display cases, possessing a link to these, but also being living collectivities which exist outside of the museum's walls and which continuously engage in processes of self definition and cultural construction.

In their rooms and galleries, museums make present collectivities which are not there, attributing meanings, values and intentions to these. Taken from villages and removed from the context of everyday and ritual use, objects found in museums' collections tend to be artificially transformed into abstract entities ( $\mathrm{x}$ people, y culture, $\mathrm{z}$ society) which

15. These were the seminars entitled Basis for new indigenous policy (I and II), which occurred at the Museu Nacional, from the $27^{\text {th }}$ to the $29^{\text {th }}$ of May, 1999 (simultaneous with the Chiefs of State Conference in Rio de Janeiro) and from the $16^{\text {th }}$ to the $18^{\text {th }}$ of December, 2002. These activities resulted in a video, a CD and several publications (see http//:www.laced.com.br). 
are disconnected from praxis and frozen with a process in which creativity and reflexivity are not be represented ${ }^{16}$. Museological initiatives always run the risk of constructing themselves solely through technical innovations of a classificatory nature, which take as their domain a mimesis of the absent collectivities while simultaneously consecrating what is essentially a relationship of political exclusion.

In the past, museums and ethnographic expositions have been machines characterized by a timelessness that seeks to suppress physical and temporal distance, promoting a logical, integrative and tranquilizing encounter between their publics and the unusual and exotic. Today's challenges, however, require different - almost completely opposite - tactics. We must pay attention not only to the contexts in which the images and objects which compose ethnography were produced, bringing into the light the colonial relationship that is frequently expressed in these, but also try recover polyphony, giving voice - and not just esthetic value - to the members of the collectivities which are generally observed by the public and translated by ethnologists. In order to move in these new directions, we must rupture theory (by abandoning old paradigms) and become politically engaged (by helping to create a better informed and more critical public).

Research conducted among today's indigenous populations in Brazil has revealed great demographic growth in the villages, increased recognition of rights over land and important environmental resources, as well as new forms of political organization and participation (Oliveira, 2001). Collectivities which had previously stopped affirming their indigenous identity and which had been understood by $19^{\text {th }}$ century administrators as « mixed», have today reclaimed a differentiated identity, becoming engaged in the reconstruction of their culture. This situation has resulted in the apparent paradox of an increase in the number of indigenous ethnic groups in Brazil ${ }^{17}$.

Though all of these processes are important, we cannot imagine that we will be able to watch paradigms shift in the same passive way in which a traveler watches landscapes unfold from his seat at the window of a train. We must modify the narcissistic relationship that museums and ethnographic expositions maintain with their habitual visitors: the great white urban public. The study of collections should be combined with ethnography and research into historical sources ${ }^{18}$ and the resulting products should be exposed to the eyes and opinions of the populations that are today descended from the ones referenced by the material ${ }^{19}$. We should struggle to use the resources we possess to help the observed populations exercise their memories and knowledge, publicizing in this way the " other histories » (Sider, 1993) that these groups construct. This is the political commitment that anthropologists, curators and museumologists should adopt.

16. It's worth remembering that ethnic objects are the result of a «travail déréalisant » (Bensa, 1995) and that centrality, through heuristic procedures of de contextualization, eventually comes to possess the theme of variation in the process of cultural production (Barth, 1987).

17. A panorama of recent studies regarding this phenomenon can be found in Oliveira (1999). After the publication of this book, two further doctoral theses regarding this theme were concluded at the Museu Nacional and both are now published. (Grunewald 2001 and Barbosa 2003).

18. According to Comaroff (1992), this means opening space in anthropology to an historic imagination.

19. This is the procedure used by Ribeiro and Van Velthem(1992:108) and named by them « recontextualization », through which they proposed to undertake collections according to new parameters (a « new collection », according to the authors upon which they base their work). 
In many ways, our intellectual routines are aligned with the paradigm that we must urgently reverse. The pretension of giving to the public a key with which to access primitiveness, for example, must be curbed. The illusion of « authenticity », whether of objects, images, or patterns of behavior, should be abandoned in favor of a continuous and multiple exercise of contextualization which attempts to understand the variability and mutability of the social forms of each human group. We must struggle to escape from purely estheticizing the Other. We need to provide the public - itself heterogenous and contradictory, including the old subjects of colonial action and not composed of generic, abstract "citizens" , the individualized expression of the homogenizing ideologies of nation states - with all the necessary elements to obtain an effective understanding of the processes by which peoples and collectivities become presented to us in one way and not another.

We must incorporate into our hypothesis and interpretations the perspective through which the facts were constructed and seriously analyze the play of identifications and differences which express the roots and locations of ourselves and the museum collections we contemplate. In other words, we must relativize our pronouncements, practicing a parallel movement of meta-reflection and seeking, as a key for comprehension, understanding of our own status as observer and our linkages to the observed. 


\section{References}

Agualusa, J. E., 2000. Um Estranho em Goa. Lisboa : Cotovia/Fundação Oriente.

Almeida, Maria Regina Celestino de, 2000. Metamorfoses indigenas. Identidade e cultura nas aldeias coloniais do Rio de Janeiro. Rio de Janeiro : Arquivo Nacional.

Almeida, Marli Auxiliadora de, 2002. Cibáe Modojebádo - a rosa Bororo e a 'pacificação'dos Bororo Coroado (1845-1887). Dissertação de mestrado. Programa de Pós-Graduação em História. UFMT. Cuiabá.

Appadurai, Arjun (ed.), 1996. The social life of things : Commodities in cultural perspective. Cambridge : Cambridge University Press.

AsAD, Talal (org.), 1973. Anthropology and the Colonial Encounter. Nova York : Humanities Press.

Barbosa, Wallace de Deus, 2003. Pedra do Encanto : Dilemas culturais e disputas políticas entre os Kambiwá e os Pipipã. Rio De Janeiro : Contra Capa Livraria.

BARTH, Frederik, 1987. CosmoLogies in the Maëing : a Generative Approach to Cultural Variation in Inner New Guinea. Cambridge : Cambridge University Press.

BAzIN, Jean, 2000. "'Science des Moeurs et Description de l'Action'. Actualités du Contemporain », in Le Genre Humain. Paris. Hiver 1999/Printemps 2000.

Bensa, Alban, 1995. « De la Micro-histoire vers une Anthropologie Critique », in J. Revel (org.), Jeux d'Echelles. Paris : Seuil/Gallimard, pp. 37-70.

Внавна, Homi K., 1994. The location of culture. New York : Routledge.

BRUnER, Edward M., 1986. « Ethnography as Narrative », in V. Turner (org.), The Anthropology of Experience. Chicago : University of Chicago Press, pp. 138-155.

Buarque de Holanda, Aurélio, 1975. Novo Dicionário da Língua Portuguesa. Rio de Janeiro: Nova Fronteira.

Carneiro da Cunha, Manuel, 1992. «Política Indigenista no Século 19 », in M. Carneiro da Cunha (org.), História dos Índios no Brasil. São Paulo : Companhia das Letras/FAPESP/SMC, pp. 133-154.

Clifford, James, 1997. Routes. Travel and translation in the late twentieth century. Cambridge : Harvard University Press.

Comaroff, John e Jean Comaroff, 1992. Ethnography and the Historical Imagination. Boulder : Westview Press.

FARIA, Luís de Castro, 1993. A Antropologia no Brasil : Espetáculo e Excelência. Rio de Janeiro : Ed. UFRJ/ Tempo Brasileiro.

Grunewald, Rodrigo de Azevedo, 2001. Os Índios da Descoberta. Rio de Janeiro : Contracapa.

Lima, Antônio Carlos de Souza, 1994. Um Grande Cerco de Paz. Petrópolis : Vozes.

Machado, Maria Fátima Roberto, 1994. Índios de Rondon. Tese de Doutoramento em Antropologia Social, Museu Nacional, UFRJ, Rio de Janeiro.

Mello Rego, Maria do Carmo de,

1895. Guido (Páginas de Dor). Rio de Janeiro : Typographia Leuzinger.

1897. Lembranças de Matto Grosso. Rio de Janeiro : Typographia Leuzinger.

1899. «Artefactos Indígenas de Matto Grosso ». Archivos do Museu Nacional, Rio de Janeiro, (10), pp. 173-184.

Monteiro, John, 1994. Negros da Terra: Índios e Bandeirantes nas Origens de São Paulo. São Paulo: Companhia das Letras.

Morel, Marco, 2000. « Índios na Vitrine : A Exposição Anthropologica Brazileira de 1882 no Rio de Janeiro ». IV Ciclo de Conferências Brasil 500 Anos - Nação e Região. Rio de Janeiro : FUNARTE. 
Nascimento, Fátima, 1991. A Imagem do Índio na Segunda Metade do Século 19. Dissertação de Mestrado, Escola de Belas Artes/UFRJ, Rio de Janeiro.

NADAF, Yasmin Jamil, 1997. « A escrita de Maria do Carmo de Mello Rego, no século 19 ». Revista do Instituto Histórico e Geográfico de Mato Grosso, 145, 101-105.

Oliveira, João Pacheco de, 1988. O Nosso Governo : Os Ticunas e o Regime Tutelar. São Paulo : Marco Zero/CNPq.

2001. «Políticas Indígenas Contemporâneas na Amazônia Brasileira », in M. A. D’Incao (org.), $O$ Brasil Não é Mais Aquele. Mudanças Sociais Após a Redemocratização. São Paulo : Cortez Editora, pp. 217-236.

(org), 1999. A Viagem da Volta : Etnicidade, Política e Reelaboração Cultural no Nordeste Indígena. Rio de Janeiro : Contracapa.

Payne, R, 1977. « The Nursery Game : Colonizers and the Colonized », in The White Arctic : Anthropological Essays on Tutelage and Ethnicity. R. Payne, (org.). Institute of Social and Economic Research. Newfoundland, Canadá : Memorial University of Newfoundland, pp. 77-106.

Ribeiro, Berta e Van Velthem, Lúcia Hussak, 1992. «Coleções Etnográficas : Documentos Materiais para a História Indígena e a Etnologia », in M. Carneiro da Cunha (org.), História dos Índios no Brasil. São Paulo : Companhia das Letras/FAPESP/SMC, pp. 103-112.

Ricardo, Carlos Alberto, 1995. «Os Índios e a Sociodiversidade Nativa Contemporânea no Brasil », in A. L. Silva e L. D. Grupioni (orgs.), A Temática Indígena na Escola. Brasília : MEC/MARI/UNESCO, pp. 29-60.

RosA, João Guimarães, 1969. «A Terceira Margem do Rio », in J. G. Rosa, Primeiras Estórias. Rio de Janeiro : Ed. José Olympio.

Schwarcz, Lilia M., 1993. O Espetáculo das Raças. Cientistas, Instituições e Questão Racial no Brasil, 1870-1930. São Paulo : Companhia das Letras.

Sider, Gerald, 1993. Lumbee Indian Histories. Cambridge : Cambridge University Press.

Steinen, Karl von den, 1940. «Entre os Aborígenes do Brasil Central ». Revista do Arquivo Municipal, v.34 a 58, São Paulo (Departamento de Cultura).

Thomas, Nicholas, 1994. Colonialism's Culture. Anthropology, Travel and Government. Cambridge : Polity Press.

Vel Zoladz, W. Rozsa, 1990. O Impressionismo de Guido, um Menino Índio Bororó. Rio de Janeiro : Ed. Universitária Santa Úrsula.

Weinstein, E., 1972. «Adoption », in D. L. Sills (org.), International Encyclopaedia of Social Sciences. Nova York : Macmillan Co. \& Free Press, 1, pp. 96-100. 